\title{
The Tritrophic System Hyptis suaveolens (Lamiaceae) - Agromyzid Leafminers (Diptera: Agromyzidae) - Parasitoids (Hymenoptera): Effects of Herbivore Density, Host Plant Patch Size, and Habitat Complexity on Parasitism Rate
}

\author{
Jarbas Marcal de Queiroz ${ }^{1 *}$ and Maria Alice Garcia ${ }^{2}$ \\ ${ }^{1}$ Departamento de Ciências Ambientais; Universidade Federal Rural do Rio de Janeiro; C.P.: 74.514; 23890-971; \\ Seropédica - RJ - Brasil. ${ }^{2}$ Departamento de Zoologia; Instituto de Biologia; Universidade Estadual de Campinas; \\ Campinas - SP - Brasil
}

\begin{abstract}
In this study a tritrophic system was evaluated to measure the contributions of the insect host density and its host plant concentration in simple and diversified habitat on the rate of parasitism. The system was composed of the plant Hyptis suaveolens, two species of agromyzid leafminers, and three morphospecies of parasitoids. The parasitism rate, patch size, and habitat complexity were found to be interdependent. If only the habitat complexity or patch size was take into account the differences in parasitism rate are not significant, although habitat diversity seemed to contribute more than the host plant concentration to increase the parasitism rate. The leaves or plants with different number of mines were equally attacked by the parasitoids. The results were representative of what happened to the leafminers at different host plant densities under the homogeneous and heterogeneous habitat condition. This work could help to reinforce the idea of the importance of the plant diversity for enhancing the biological control of the pests by the parasitoids in the managed ecosystems.
\end{abstract}

Key words: Habitat heterogeneity, Calycomyza, Chrysocharis, Biological control

\section{INTRODUCTION}

It seems reasonable that the density and dispersion of the herbivore hosts among the plants are factors related to the rate at which they are attacked by the parasitoids. Stiling (1987) reported that in only about $25 \%$ of the cases studied, the parasitoid response was directly dependent on the host density, while in $52 \%$ of the cases, no relation between the parasitism rate and host density was observed. Other factors, such as the host plants
(Barbosa and Benrey ,1998; Gratton and Welter, 2001; Till et al., 2002), habitat and environmental factors (Kareiva, 1983; Nichols and Altieri, 1994; Gurr et al., 2003), as well as variation in the foraging behavior among the herbivore host species (Hawkins, 1994) and parasitoid species (Stiling, 1987; Casas, 1989; Lewis et al., 1990) seem to be important in explaining the variations in the parasitism rate. Therefore, although obviously relevant, the host density, by itself, is

*Author for correspondence: jarbas@ufrrj.br 
not enough to determine the parasitism rate on the phytophagous insects.

For each particular phytophagous species, both intrinsic factors to the host plant-herbivoreparasitoid system and extrinsic habitat factors must be taken into account when analyzing the role of the parasitoids in herbivore's population dynamics. Barbosa and Benrey (1998) observed that the high resource availability of the diversified habitats could increase a parasitoid's fecundity, longevity, survival, and rate of the parasitism. Such a positive correlation has been ascribed to the higher availability of the resources provided by a more diverse plant community, such as the shelter and food supplies (e.g. nectar, pollen, and honeydew) (Root 1973, Powell 1986). Also, the habitat structure, particularly the plant species dispersion and composition, affect the parasitoids by interfering with the host location mechanisms, which are mainly based on the detection of the chemical and visual signals directly emanating from the host plants or mediated by the herbivores feeding on them (Vinson, 1976; Price et al., 1980; Whitam and Eller, 1990; Vet and Dicke, 1992; Godfray, 1995). Because of the higher concentration of the specific volatiles, the places where the host plants are concentrated, such as monocultures, would be expected to attract more parasitoids particularly associated with the herbivores feeding on these plants (Vet and Dicke, 1992). However, it has been demonstrated that not only the parasitoid richness, but the parasitoid abundance as well, tend to be higher in more complex habitats (Risch, 1979; Botelho et al., 1994).

Usually, a guild of the herbivores, such as the agromyzid leafminers, is attacked by a complex of parasitoids. The relative contribution of a particular species or group of the parasitoid species, through mortality, to a leafminer guild's population dynamics may depend on a combination of factors, which includes the density of the host herbivores, concentration of their host plants, and other features of the habitat where the insect hosts are found (Price et al., 1980; Damman, 1990). However, most of the studies aiming to analyze the insect host-parasitoid interactions refer to oversimplified systems of one host - one parasitoid species, or deal more with the community approaches to complex food webs. Despite the relevance of these approaches, in many systems the focus of one is too broad, and of the other too narrow to optimally measure the effects of the increased plant density and/or diversity on the tritrophic interactions in the agroecosystems.

Focusing on the systems having an intermediate level of the complexity, such as those composed of one plant species, and multiple insect species depending on it, constitutes an interesting approach to investigate the effects of the host plant dispersion, herbivore density and habitat factors on the parasitism rate. This kind of information on the basic aspects of the tri-trophic interactions can help guide the biological control programs (Dyer and Gentry, 1999).

The present study aimed to evaluate the effects of the insect host density and host plant concentration at the simple and diversified habitat on the parasitism rate of the agromyzid leafminers living on Hyptis suaveolens Poit.

\section{MATERIALS AND METHODS}

\section{The system studied}

The system Hyptis suaveolens Poit. (Lamiaceae)agromyzid leafminers - parasitoids was studied from November 1994 to August 1995, in the Serra do Japi $\left(23^{\circ} 11^{\prime} \mathrm{S}, 46^{\circ} 52^{\prime} \mathrm{W}\right)$, Brazil, hereafter referred to as Japi. Japi is a protected area, with $300 \mathrm{Km}^{2}$, covered by a semideciduous forest, near the City of São Paulo. Patches of H. suaveolens are commonly found on the borders of the trails and roads crossing the area. Hyptis suaveolens is a native annual herbaceous plant commonly found in agricultural systems and in the open areas (Leitão Filho et al., 1972; Lorenzi, 1991).

The leafminers from the genus Calycomyza Hendel (Diptera: Agromyzidae) were found attacking $H$. suaveolens at Japi. The blotch mines containing the last instar (third) can measure up to $1.5 \mathrm{~cm}^{2}$. The adults, ca. $2 \mathrm{~mm}$ long, can be seen on either surface of $H$. suaveolens leaves.

\section{Parasitism of agromyzid leafminers in natural conditions}

A total of 344 mined leaves of $H$. suaveolens was collected from November 1994 to May 1995. During this period of the year, the host plant occurred at the highest abundance and looked most vigorous. The collections took place along a $5 \mathrm{~km}$ trail, representing an altitudinal gradient from 800 $\mathrm{m}$ to $1100 \mathrm{~m}$ above the sea level. The collection was done at six different areas where $H$. suaveolens was abundant, three at $800 \mathrm{~m}$, one at 
$900 \mathrm{~m}$, one at $1000 \mathrm{~m}$, and one at $1100 \mathrm{~m}$ altitude. In each area, a total of 10 random collections of mined leaves were made distributed as follows: one in Nov/94, two in Dec/94, two in Jan/95, one in Feb/95, one in Mar/95, two in Apr/95, and one in May/95. The collected leaves were individually separated in small plastic bags, which were labeled and taken to the laboratory where they were kept at room temperature. The emerged adults of both the leafminers and parasitoids were recorded and preserved for later identification.

\section{Effect of leafmine density on parasitism in natural conditions.}

During April and May 1995, 95 plants of $H$. suaveolens, occurring isolated from each other in the forest border, were inspected. Only the plants carrying at least one leafminer larvae at the last instar were sampled. The collection was restricted to larvae at this stage to guarantee that these mines had been exposed to the parasitoids during the similar amount of time, and also to reduce the variability in the survival rate of both the host and parasitoids. The inspections were carried out along a trail at $800 \mathrm{~m}$ altitude. The number of mined leaves per plant and the number of mines per leaf were recorded. The mined leaves were separated in the plastic bags, labeled, and taken to the laboratory where the same methodology, as described above, was followed.

\section{Effect of host plant patch size and habitat heterogeneity on parasitism.}

Three experiments were set between April and August 1995 at the Japi Field Station at $800 \mathrm{~m}$ altitude. About 1000 seedlings from $H$. suaveolens were collected from the forest border and transplanted in the plastic bags containing one part of the potting soil and two parts of the soil from the experimental area. These seedlings were initially left to grow close to the experimental area. All the seedlings were continuously inspected and all the mined leaves were removed before installing the experiment. For all the experiments different numbers of the potted plants were taken at random (about $20 \mathrm{~cm}$ ) to establish the different sized patches of the treatments.

Two areas were used as the arenas for the experiment. One was a grass field of $450 \mathrm{~m}^{2}$ (area A), representing an homogeneous habitat, and the other was an old orchard of $525 \mathrm{~m}^{2}$ (area B), representing an heterogeneous habitat. The exact position of each patch in the arena in each experiment, was determined randomly. Each patch was installed at least $5 \mathrm{~m}$ apart from the nearest patch. The pots composing the same patch were joined together and Tanglefoot ${ }^{\circledR}$ was applied to avoid attack of the plants by Atta sp. (Hymenoptera, Formicidae). Each day for the following 10 days, the plants were inspected and all mines were removed. This procedure was adopted to guarantee that all mines and parasitoids recorded had colonized the plants after the experiment had been installed. After this period, the number of mines per plant and per leaf in each patch was counted. The mined leaves were collected and the mines were raised in laboratory using the same technique previously described.

The experiments differed in the patch sizes and distribution pattern of the treatments. In the area A (grass field) two trials were made. The first one had four patch sizes: 1, 10, 20, and 30 plants/patch, with 13 replicates for the isolated plant treatment and 5 replicates for the other patch size treatments. The inspections were carried out five times from April to May. For the second trial in the area A, the largest patch size was increased, using patches of 1,10 , and 50 plants each, with 18 replicates for isolated plants and five replicates for each of the other patch size treatments. The inspections were carried out five times from June to August. In the area B (old orchard) only two patch sizes were used: 1 and 20 plants each, with 20 replicates for the isolated plants and six for the aggregated plants. Inspections were carried out nine times from April to August.

\section{Statistical analysis}

The total number of insects, both leaf-miners and parasitoids, which emerged from the leaves, were used to calculate the percent parasitism (similar methodology was applied by Friedlander et al., 1985 and by Kahn and Cornell, 1989). Other mortality factors were not considered. Although the mortality due to abortion of the mines in the laboratory could differ between the parasitized and not parasitized mines, this source of the error was evenly distributed among the patch sizes and habitats treatments. The statistical tests applied to compare the differences in the frequency and proportion of the agromyzids and parasitoids emerged from the mines per plant and per leaf and from the aggregated and isolated plants in simple (grass field) and complex habitat (old orchard). The analyses were carried out using Qui-Square 
test, $\mathrm{G}$ test, and multidimensional contingency table analysis as described by Zar (1996).

\section{RESULTS}

\section{The System H. suaveolens-Agromyzidae- parasitoids.}

The $H$. suaveolens-agromyzid-parasitoids system in Southeast Brazil is composed of two species of agromyzid, Calycomyza hyptidis (L.) Poit. and another Calycomyza species (unidentified) (Calycomyza sp2), and three morphospecies of the parasitoids, Chrysocharis sp1, C. $\quad \mathrm{sp} 2$ (Eulophidae), and one species from the family Eucoilidae (Eucoilidae sp1). No other species of leafminer or leafminer parasitoid on $H$. suaveolens was found. At all the places surveyed, the Calycomyza sp2 was more common than $C$. hyptidis (Fig. 1), and often the both species cooccurred in the same leaf. The two agromyzid species were easily distinguished from each other. Calycomyza sp2 formed a blotch mine located on the basal portion of the leaf, usually on the side of the mid vein, while $C$. hyptidis produced a star shape mine located on the apical portion of the leaf, often exactly over the mid vein.

\section{Overall parasitism in natural conditions}

From the 344 mined leaves collected along the altitudinal transect, between November 1994 and May 1995 (summer and autumn), 58 adult Calycomyza (about $84 \%$ C. sp2. and $16 \% \quad C$. hyptidis) and 83 parasitoids ( $41 \%$ from $C . \mathrm{sp} 2$ mines and 59\% from the $C$. hyptidis) mines were obtained. Among the emerged parasitoids, Chrysocharis sp1 was the most common (39 adults), followed by Chrysocharis sp2 (29) and the least common was Eucoilidae sp1 (15) (Fig. 1).

\section{Effect of leafminer density on parasitism rate.}

Of the 95 colonized plants that were naturally occurring isolated in the forest border, 52 had only one individual leafmine of Calycomyza, while 43 plants had more than one leafmine and the maximum was 15 leafmines per plant. Although the leafmines on the plants carrying more than one mine suffered about $10 \%$ more parasitism than the ones occurring isolated, this difference was not statistically significant (Fisher modified test, $\mathrm{P}=$ 0.159 ).

The maximum number of the mines per leaf was six, and the leafmines occurring alone (one per leaf) and aggregated (more than one per leaf) were almost equally attacked by the parasitoids (Fisher modified test, $\mathrm{P}=0.472$ ). Therefore, neither the leafminer density per plant, nor the leafminer density per leaf seemed to be clearly related with the parasitism rate of Calycomyza on the leaves of $H$. suaveolens in the natural conditions.

Effect of host plant patch size and habitat complexity on parasitism of leafmines.

From the total of 764 leafmines that colonized the plants in the experimental arenas, 127 adult insects emerged, 39 flies and 88 parasites, giving a parasitization rate of $69 \%$. The absolute frequencies of the parasitoids successfully raised were not independent of the combined effects of patch size and habitat condition (Table $1, \mathrm{G}=$ 22.88; $\mathrm{DF}=1 ; \mathrm{P}<0.001)$. The numbers of the agromyzid parasitized, patch size, and habitat complexity were shown to be interdependent variables (Table $2, \chi^{2}$ for the mutual independence $=32.45, \mathrm{DF}=4 ; \mathrm{P}<0.001)$. However, taking into account only the habitat complexity, although the parasitism rate was about 14\% higher in the heterogeneous habitat, this difference was not significant (Fisher modified test, $\mathrm{P}>0.05$ ). Otherwise, when taking into account only the patch size, the parasitism rate was even more similar between isolated and aggregated plants (64\% and $72 \%$, respectively) (Fisher modified test, $\mathrm{P}=0.31$ ). The parasitism rate proved to be only marginally dependent of the other two variables together (Table 2, $\chi^{2}=7.269, \mathrm{DF}=3 ; \mathrm{P}<0.10$ ).

The final result of this interaction on the third trophic level, when the effects of host plant patch size and habitat on the herbivore and on its parasitoids were combined, was that the parasitism rate was the lowest (44\%) for the leafminers in the isolated plants in the homogeneous habitat, and the highest $(85 \%)$, for the leafminers in the grouped plants in the heterogeneous habitat (Table 3). 
Parasitoids

$\begin{array}{ccc}\text { Chrysocharis sp1 } & \text { Chrysocharis sp2 } & \text { Eucoilidae sp1 } \\ (\mathbf{4 7 \%}) & (\mathbf{3 5 \%}) & (\mathbf{1 8 \%})\end{array}$

Leafminers

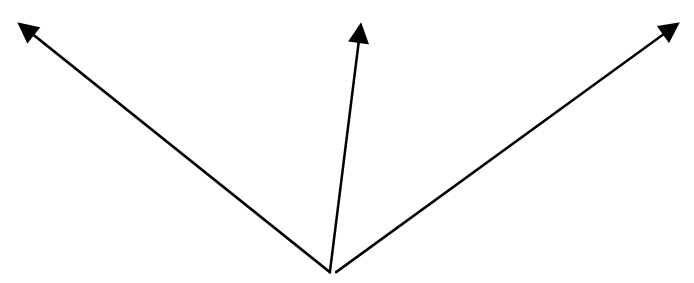

\section{Host plant}

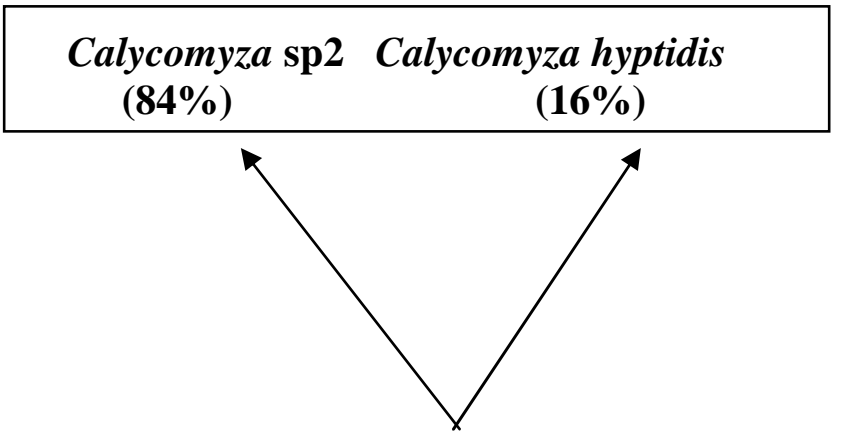

\section{Hyptis suaveolens}

Figure 1 - Tritrophic system Hyptis suaveolens - Calycomyza leafminers - parasitoids in the Serra do Japi, Southeast, Brazil.

Table 1 - Frequency of microhymenoptera parasitoids emerging from Calycomyza leafminers in experiments with isolated and aggregated host plant Hyptis suaveolens in homogeneous (grass field) and heterogeneous habitats (old orchard).

\begin{tabular}{|c|c|c|c|c|c|}
\hline & Homogeneous habitat & Heterogeneous habitat & Total & $\mathbf{G}$ & $\mathbf{P}$ \\
\hline Isolated plant & 8 & 22 & 30 & 22.88 & $<0.001$ \\
\hline Aggregated plants & 47 & 11 & 58 & & \\
\hline Total & 55 & 33 & 88 & & \\
\hline
\end{tabular}

*P for $\chi^{2}{ }_{0.05,1}=3,841$

Table 2 - Three-dimentional contingency table for mutual and partial independence analysis among parasitism (parasitized x not parasitized), host plant density (isolated x patched), and habitat (homogeneous x heterogeneous) in the system Hyptis suaveolens - Calycomyza spp. leafminers - microhymenoptera parasitoids.

\begin{tabular}{lccccc}
\hline & \multicolumn{2}{c}{ Homogeneous habitat } & \multicolumn{2}{c}{ Heterogeneous habitat } & Total \\
\cline { 2 - 6 } & Isolated plants & Aggregated plants & Isolated plants & Aggregated plants & \\
\cline { 2 - 6 } Parasitized & 8 & 47 & 22 & 11 & 88 \\
Not parasitized & 10 & 20 & 7 & 2 & 39 \\
\hline Total & 18 & 67 & 29 & 13 & 127 \\
\hline
\end{tabular}

\section{$\chi^{2}$ for total independence}

$\chi^{2}=32.453 \quad \mathrm{P}<0.001 \quad\left(\chi_{0.05,4}^{2}=9.488\right)$

$\chi^{2}$ for parasitism independent of habitat and plant density

$\chi^{2}=7.2690 .05<\mathrm{P}<0.10 \quad\left(\chi_{0.05,3}^{2}=7.815\right)$ 


\section{DISCUSSION}

\section{Parasitism rate on leafminers}

The leafminer parasitoids certainly exert strong effect on the insect host population dynamics. The high parasitism rate observed for Calycomyza species on $H$. suaveolens in Southeast Brazil, reinforced the idea, which had already been reported for the insect-plant systems studied in the temperate regions that parasitoids represented an important top-down mortality factor for the herbivore insects (Price, 1992). Esposito (1990), working in the same region reported $43 \%$ of parasitism rate for agromyzid pupae collected from the herbaceous plants community. In the natural habitats of Central Argentina, Valladares and Salvo (2001) also found high rates of the parasitism on the agromyzid leafminers, particularly during the summer (December to March), when over $70 \%$ of the leafmines had been parasitized.

\section{Density dependence and habitat heterogeneity effects on parasitism rate}

While the density of the leafminers per plant and per leaf seemed not to be related to parasitism rate, the patch size of the herbivore's host plant, as well as the habitat heterogeneity seemed to affect parasitoid numbers. It was found that Calycomyza species are more prone to escape from parasitoids when in isolated plants in the homogeneous habitat, and that the parasitism rate tended to be the highest when the leafminers occurred in the patched host plants in more diversified habitat. The habitat heterogeneity seemed to be relatively more important than the host plant density for explaining the differences in the parasitism rate in this tritrophic system. The presence of other herbs, shrubs and trees in the heterogeneous habitat probably contributed additional resources that might have positively affected the parasitoids, resulting in higher parasitism rate.

A possible, but not exclusive explanation, could be the well known positive role of the complementary and supplementary food sources and microclimate conditions in a more complex environment on the parasitoid efficiency (Barbosa and Benrey, 1998; Marino and Landis, 1996). Landis et al.(2000) suggested that the spatial and temporal management of the resources such as the alternative food, alternative prey, and shelter in the habitat was a key factor for the improvement of the herbivore population control by the natural enemies.

Therefore, although the parasitism rate considered in this study did not take into account the differences among agromyzid and parasitoid species involved, the proportion of both the agromyzid hosts did not differ between areas (Calycomyza sp. is always more abundant, about $85 \%$ of the total) and that the combined species analyzed represented a common interactive situation. From the point of view of the response of the parasitoids as a top-down factor, the results were representative of what happened to the leafminers at different host plant densities under the homogeneous and heterogeneous habitat condition. Thus, it could be concluded that: 1 . the number of mines per plant and per leaf had marginal or no effect on parasitism rate; 2 . the patch size of the herbivore's host plant, as well as the habitat heterogeneity seemed to affect the parasitism rate; 3 . habitat diversity seemed to contribute more than the host plant concentration for increasing the parasitism rate. These conclusions reinforced the idea of the importance of the flora diversity for enhancing the biological control of the specialist pests by the parasitoids in the agroecosystems. If this is true, the conservation of the biodiversity of the parasitoids in one tropical region could be more directly dependent on the conservation of the plant diversity.

\section{ACKNOWLEDGEMENTS}

We thank Dr. Paul G. da Silva, Dr. Thomas M. Lewinsohn, and two anonymous referees for their helpful comments on the manuscript. JMQ was a fellow from CNPq (Brazilian Federal Government Support for Science Development). We also thank the staff of Serra do Japi Field Station and from the Department of Zoology at Campinas State University.

\section{RESUMO}

Foi avaliado um sistema tritrófico para medir os efeitos da densidade de insetos minadores e a concentração da planta hospedeira em habitats simples e diversificados sobre a taxa de parasitismo. O sistema era composto pela planta Hyptis suaveolens, duas espécies de agromizídeos 
minadores de folhas e três morfoespécies de parasitóides. A taxa de parasitismo, tamanho da mancha e a complexidade do habitat foram interdependentes. Se levarmos em consideração apenas a complexidade ou tamanho de mancha, as diferenças na taxa de parasitismo não foram significativas, embora a diversidade de habitat pareça ter contribuido mais do que a concentração da planta hospedeira para aumentar a taxa de parasitismo. Folhas ou plantas com diferentes números de minas foram igualmente parasitadas. Nossos resultados são representativos do que acontece com insetos minadores em diferentes densidades de plantas e condição do ambiente homogêneo ou heterogêneo. Este trabalho ajuda a reforçar a idéia de que a diversidade de plantas no sistema ajuda a aumentar o controle biológico de pragas por parasitóides.

\section{REFERENCES}

Barbosa, P. and Benrey, B. (1998), The influence of plants on insect parasitoids: Implications for conservation biological control. In: Barbosa, P. (ed.). Conservation Biological Control.Academic Press, San Diego. pp. 55-82

Botelho, A.C.B.; Cure, J.R. and Vilela, E.F. (1994), Abundância e riqueza em espécies de insetos (herbívoros, predadores e parasitóides) em agroecossistema hortícola com manejo orgânico. Anais da Sociedade Entomológica do Brasil, 23: 87-98.

Casas, J. (1989), Foraging behaviour of a leafminer parasitoid in the field. Ecological Entomology, 14: 257-265.

Damman, H. (1990), Patterns of interactions among herbivore species. In: Stamp, N.E. and Casey, T.M. (eds.). Catterpilars: Ecological and Evolutionary Constraints on Foraging. Chapman and Hall, New York. pp. 132-169.

Dyer, L.A. and Gentry, G. (1999), Predicting naturalenemy responses to herbivores in natural and managed systems. Ecological Applications, 9: 402-408.

Esposito, M.C. (1990), Taxonomia e ecologia das moscas minadoras de folhas (Diptera: Agromyzidae) de três áreas da região de Campinas, São Paulo, Brasil. MSc Thesis, Universidade Estadual de Campinas.

Friedlander, T.P.; R.A. Wharton, R.A. and Steck, G.J. (1985), New records of agromyzid and their braconid parasitoids from Texas. The Southwestern Entomologist, 10: 257-263.

Godfray, H.C.J. (1995), Communication between the first and third trophic levels: an analysis using biological signalling theory. Oikos, 72: 367-374.

Gratton, C. and Welter, S. (2001), Parasitism of natural populations of Lyriomyza helianthi Spencer and
Calycomyza platyptera (Thompson) (Diptera: Agromyzidae). Biological Control, 22:81-97.

Gurr, G. M.; Wratten, S.D. and Luna, J. (2003), Multifuction agricultural biodiversity: pest management and other benefits. Basic and Applied Ecology, 4:107-116.

Hawkins, B.A.(1994), Patternand Process in HostParasitoid Interaction. Cambridge University Press, New York.

Kahn, D.M. and Cornell, H.V. (1989), Leafminers, early leaf abscission, and parasitoids: A tritrophic interaction. Ecology, 70: 1219-1226.

Kareiva, P. (1983), Influence of Vegetational Texture on Herbivore Populations: Resource Concentration and Herbivore Movement. In: R.F. Dennoand McClure, M.S. (eds.) Variable Plants and Herbivores in Natural and_Managed Systems. Academic Press, New York. pp. 259-289

Landis, D.A.; Wratten, S.D. and Gurr, G.M.(2000), Habitat management to conserve natural enemies of arthropod pests in agriculture. Annual Review of Entomology, 45: 175-201.

Leitão-Filho, H.F.; Aranha, C. and Bacchi, O. (1972), Plantas Invasoras de Culturas no Estado de São Paulo. Vol. 1. Hucitec, São Paulo.

Lewis, W.J.; Vet, L.E.M.; J.H. Tumlinson, J.H.; Van Lenteren, J.C. and D.R. Papaj, D.R. (1990), Variations in parasitoid foraging behavior: essential element of a sound biological control theory. Environmental Entomology, 19: 1183-1193.

Lorenzi, H. (1991), Plantas Daninhas do Brasil. 2 Edição. Editora Plantarum Ltda.

Marino, P.C. and Landis, D.A. (1996), Effect of landscape structure on parasitoid diversity and parasitism in agroecosystems. Ecological Applications, 6: 276-284.

Nicholls, C.I. and Altieri, M.A. (1994), The agroecological basis of ecological engineering for pest management. In: Gurr, G.M., S.D. Wratten and M.A. Altieri (eds.). Ecological engineering for pest management: advances in habitat manipulation for arthropods. CSIRO publications, New Zealand. pp. 33-54.

Powell, W. (1986), Enhancing Parasitoid Activity in Crops. Insect Parasitoids. (ed. by J. Waage and D. Greathead), pp. 319-341, Academic Press, London.

Price, P. (1992), Plant resources as the mechanistic basis for insect herbivore population dynamics. In: Hunter, M.D.; Ohgushi, T. and Price, P.W. (eds.). Effects of Resource Distribuition on Animal-Plant Interactions, Academic Press, Inc., New York. pp. 139-173.

Price, P.;Bouton, C.E.;Gross, P.;McPheron, B.A.; Thompson, J.N. andWeis, A.E. (1980), Interaction among three trophic levels: Influences of plants on interactions between insect herbivores and natural enemies. Annual Review of Ecology and Systematics, 11: 41-65.

Risch, S.J. (1979), A comparison, by sweep sampling, of the insect fauna from corn and sweet potato 
monocultures and dicultures in Costa Rica. Oecologia, 42: 195-211.

Root, R.B. (1973), Organization of a plant-arthropod association in simple and diverse habitats: The fauna of collards (Brassica oleraceae). Ecological Monographs, 43: $95-124$.

Stiling, P.D. (1987), The frequency of density dependence in insect host-parasitoid systems. Ecology, 68: 844856.

Till, J.T.; Marquis, R.J. and Ricklefs, R.E. (2002), Host plant influence parasitism of forest caterpillars. Nature, 417:170-173.

Valladares, G.R. and Salvo, A. (2001), Community dynamics of leafminers (Diptera: Agromyzidae) and their parasitoids (Hymenoptera) in a natural habitat from Central Argentina. Acta Oecologica, 22: 301309.

Vet, L.E.M. and Dicke, M. (1992), Ecology of infochemical use by natural enemies in a tritrophic context. Annual Review of Entomology, 37: 141-172.

Vinson, S.B. (1976), Host selection by insect parasitoids. Annual Review of Entomology, 21: 109-134.

Whitam, D.W. and Eller, F.J. (1990), Parasitic wasps orient to green leaf volatiles. Chemoecology, 1: 6975.

Zar, J. H. (1996), Biostatistical Analysis. Third Edition. Prentice-Hall. USA. 